\title{
Assessment of body posture in women after radical mastectomy using the DIERS formetric III 4D device
}

\section{Ocena postawy ciała kobiet po radykalnej mastektomii za pomoca urzadzenia DIERS formetric III 4D}

\author{
Magdalena M. Kabała ${ }^{1,2}$, Paulina Jasek ${ }^{1,3}$, Jacek Wilczyński ${ }^{1}$ \\ ${ }^{1}$ Collegium Medicum, Jan Kochanowski University, Kielce, Poland \\ Head of the Collegium: Prof. Marianna Janion MD, PhD \\ ${ }^{2}$ Department of Rehabilitation, Holy Cross Cancer Centre, Kielce, Poland \\ Head of the Department: Anna Opuchlik MD, PhD \\ 3Department of Anaesthesiology and Intensive Care, St. Rafal's Provincial Specialist Hospital, Czerwona Gora, Poland \\ Head of the Department: Jacek Lech MD
}

Key words: body posture, mastectomy, DIERS formetric III 4D.

Słowa kluczowe: postawa ciała, mastektomia, DIERS formetric III 4D.

\begin{abstract}
Introduction: Body posture is an individual and variable feature determined on a muscular, neurophysiological, osteoarticular or environmental basis. One-sided mastectomy as well as its negative effects and the treatment process are factors causing disturbances in body posture.

Aim of the research: To assess the posture of women after mastectomy depending on the side of the procedure.

Material and methods: The study group consisted of 30 women after mastectomy (right-sided, left-sided) and 30 healthy women aged 45 to 60 years. All examined patients were right-handed; 13 women underwent left-sided radical mastectomy, and 17 women right-sided. The criterion for including patients in the study was a period of 3-4 years after breast cancer surgery. Body posture was assessed using the DIERS formetric III 4 D optoelectronic method. The study was performed at the Posturology Laboratory of Collegium Medicum, Jan Kochanowski University in Kielce.

Results and conclusions: The Mann-Whitney $U$ test showed a statistically significant difference in the pelvic tilt parameter between the group of women following right- and left-sided mastectomy $(p=0.034)$. In women following mastectomy, a greater number of abnormal postures was noted, especially with a tendency towards deepened thoracic kyphosis and lumbar lordosis compared to the control group. Statistical significance was demonstrated in relation to the lordosis angle of the lumbar spine between groups $(p=0.047)$. Women after left-sided mastectomy exhibited higher scoliosis angle, vertical deviation, lateral deviation and surface rotation relative to women after right mastectomy.
\end{abstract}

\section{Streszczenie}

Wprowadzenie: Postawa ciała jest cechą indywidualną i zmienną, kształtującą się na podłożu mięśniowym, neurofizjologicznym, kostno-stawowym i środowiskowym. Mastektomia jednostronna i jej negatywne skutki oraz proces leczenia należą do czynników zaburzających postawę ciała.

Cel pracy: Ocena postawy ciała kobiet po mastektomii w zależności od strony, po której wykonano zabieg.

Materiał i metody: Grupę badaną stanowiło 30 kobiet po mastektomii (prawostronnej, lewostronnej) oraz 30 kobiet zdrowych w wieku od 45 do 60 lat. Wszystkie pacjentki były praworęczne, u 13 kobiet wykonano radykalną mastektomię lewostronną, natomiast u 17 kobiet mastektomię prawostronną. Kryterium włączenia pacjentek do badań był czas 3-4 lat od zabiegu chirurgicznego raka piersi. Postawę ciała oceniono metodą optoelektroniczną DIERS formetric III 4D. Badania wykonano w Laboratorium Posturologii Collegium Medicum Uniwersytetu Jana Kochanowskiego w Kielcach.

Wyniki i wnioski: Test $U$ Manna-Whitneya wykazał istotną statystycznie różnicę w parametrze skośności miednicy pomiędzy grupą kobiet po mastektomii prawostronnej i lewostronnej $(p=0,034)$. U kobiet po mastektomii częściej występowała sylwetka kifotyczna w odcinku piersiowym z pogłębieniem lordozy w odcinku lędźwiowym w porównaniu z grupą kontrolną. Stwierdzono istotność statystyczną w odniesieniu do kąta lordozy odcinka lędźwiowego pomiędzy grupami $(p=0,047)$. U kobiet po mastektomii lewostronnej wykazano większy kąt skoliozy, większe odchylenie od pionu i odchylenie boczne oraz większą rotację powierzchni niż u kobiet po mastektomii prawostronnej. 


\section{Introduction}

Posture of the human body undergoes modification during the ontogenetic process, and the changes depend both on external (trauma) and internal factors (disease). Undoubtedly, the disease which is breast cancer, its negative effects and the treatment process itself are factors causing disturbances to body posture. As a result of the surgical procedures, the long thoracic nerve and thoracodorsal nerve can be damaged, which leads to muscle paralysis, responsible for impaired mobility in the shoulder joint $[1,2]$. In addition, adjuvant treatments such as radiation or chemotherapy can contribute to functional defects or muscle atrophy. Breast amputation is also associated with numerous complications, including secondary lymphedema, thoracic hyperkyphosis and scoliosis [3]. Postural defects are the consequence of pathological changes; they can affect all planes of the body, but they are usually manifested by changes in the shape of the spine and the sections associated with it [4]. In the case of women after mastectomy, the prosthesis on the operated side and lateral curvature of the spine may affect the body posture of the examined women [5-7].

\section{Aim of the research}

Thea aim of the study was to assess body posture in women following mastectomy depending on the side of the performed surgery.

\section{Material and methods}

The study comprised 60 females. The study group consisted of 30 women after mastectomy (right-, leftsided) and 30 healthy women with similar anthropometric parameters aged 45 to 60 (mean: $51.9 \pm 8.1$ ) years. The criterion for including patients in the study was a period of 3-4 years after breast cancer surgery. All examined patients were right-handed, 13 women were subjected to left-sided radical mastectomy, while 17 women underwent the procedure on the right side. Of the adjuvant treatment, radiation therapy was implemented in $76.7 \%$, followed by hormonal therapy in $73.3 \%$ and chemotherapy in $63.3 \%$. The examined group did not have lymphedema. Basic somatic features were tested. Body height was measured using an anthropometer to the nearest $5 \mathrm{~mm}$, while body mass was evaluated using an electronic scale to the nearest $0.5 \mathrm{~kg}$. Based on the obtained data, body mass index was calculated.

Body posture was assessed using the DIERS formetric III 4D optoelectronic method. The method allows photogrammetric video recording of the back surface using the raster stereography process. Based on the obtained data, a precise, three-dimensional model of the back surface is created. The essence of the device is analysis of the back form. Taking into account the anatomical and biomechanical assumptions of the model, it is possible to calculate constant anatomical points, spinal curvatures and the spatial form parameters of the trunk resulting from these calculations [8].

The following parameters were used to analyse body posture:

- deviation from the vertical VP - DM mm (trunk imbalance). Deviation from the vertical line means the lateral deviation of the point in the middle of the neck (vertebra prominens) from the midpoint between the lumbar dimples DL - DR to the left or right;

- lateral deviation VPDM (rms) $\mathrm{mm}$. This is the mean square deviation of the midline of the spine from the VP-DM line in the frontal plane. Nomenclature: $\mathrm{R}$ (positive; average lateral deviation to the right), $\mathrm{L}$ (negative, average lateral deviation to the left);

- pelvic tilt DL - DR mm. Pelvic tilt refers to the difference in the height of the lumbar dimples in relation to the horizontal plane (cross-section). A positive value means that the right dimple is higher than the left dimple, while a negative value occurs when the right dimple is located below the left dimple;

- pelvic torsion DL - $\mathrm{DR}^{\circ}$ (pelvic torsion). Pelvic torsion is calculated from mutual torsion and the normal plane at the points of the lumbar dimples (vertical component). With a positive difference in angles, the normal one on the right dimple (DR) is pointed further upwards than on the left one. Nomenclature: + (positive; DR curve points further upwards than DL), - (negative; DR curve points further downwards than DL);

- surface rotation $(\mathrm{rms})^{\circ}$. This parameter means the root mean square of surface rotation on the symmetry line. Nomenclature: R (positive; average surface rotation to the right), $\mathrm{L}$ (negative, average surface rotation to the left);

- kyphotic angle ICT - ITL (max.) $)^{\circ}$. This is the maximum kyphotic angle measured between the tangent to the surface of the upper ICT inflection point (the point of highest positive surface inclination within the neck, above the kyphosis apex) near VP and the thoracic-lumbar ITL inflection point (thoracic-lumbar inflection point, i.e. the highest negative surface inclination point in the area between the kyphosis and lordosis apexes);

- lordotic angle ICL - ITS (max.) ${ }^{\circ}$. This is the maximum lordotic angle, measured between tangents with regard to the thoracic-lumbar ITL inflection point and the lower lumbar-sacral ILS inflection point (the point of the highest positive surface inclination in the area between the lordosis apex and the sacral segment);

- scoliosis angle. The measurement with the DIERS formetric III $4 \mathrm{D}$ apparatus concerns only the spine itself and shows the angle of curvature from $1^{\circ}[9]$. 
Serious eyesight disorders and significant disturbances in balance (orthopaedic, neurological, rheumatological) were criteria excluding patients from the study group. All parameters recorded by the DIERS formetric III $4 \mathrm{D}$ were collected in a completely noninvasive manner, and the device was safe for the study group. The study was performed in 2019 at the Posturology Laboratory of Collegium Medicum, Jan Kochanowski University in Kielce.

\section{Statistical analysis}

The obtained parameters were recorded in one database and statistically analysed. Arithmetic mean, standard deviation (SD), medians, etc., were used to assess the variables.

The Mann-Whitney $U$ test was used to determine correlations between body posture parameters and the side of the performed mastectomy. The results were recorded using Statistica 13 software.

\section{Results}

Women after right mastectomy constituted the majority of the study group (56.7\%), while $43.3 \%$ of women underwent left mastectomy. The average age of the examined groups, including the control, was 51.9 years, with a standard deviation of \pm 8.14 Statistical significance in terms of age $(p<0.001)$, body weight ( $p=0.021)$ and body mass index (BMI) ( $p=0.049$ ) between the study group and the control group was demonstrated (Table 1).

Body posture parameters were analysed in the examined and control groups. In the study group, flattened kyphosis in the thoracic spine was observed in 2 (6.7\%) women, and deepened kyphosis in 17 (56.7\%) women. The normal kyphosis angle in the thoracic segment is between $42^{\circ}$ and $55^{\circ}$. Normal kyphosis was demonstrated in $11(36.7 \%)$ women. The mean kyphosis angle in the examined group was $57.13^{\circ}$, standard deviation 11.70 , median value 58.50 , the range between the lower and upper quartile was from $47-62^{\circ}$, and the total range was 33-80. In the control group, flattened kyphosis in the thoracic spine was observed in $5(16.7 \%)$ women, and deepened kyphosis in 14 (46.7\%) women. Normal kyphosis was demonstrated in $11(36.7 \%)$ women. The mean kyphosis angle in the study group was $52.77^{\circ}$, standard deviation 9.32 , median value 54 , range between the lower and upper quartile 49-60, and the total range 31-66.

In the study group, flattened lordosis in the lumbar segment was observed in 2 (6.7\%) women, and deepened lordosis in 21 (70\%) women. The norm of the lordosis angle in the lumbar region is within 33$47^{\circ}$. Normal lordosis was demonstrated in 7 (23.3\%) women. The mean lordosis angle in the study group was $53.43^{\circ}$, standard deviation 12.81 , median value 54.50 , the range between the lower and upper quartile 44-59, and the total range 27-79. In the control group, flattened lordosis in the lumbar segment was observed in 3 (10\%) women, and deepened lordosis in $15(50 \%)$ women. Normal lordosis was observed in $12(40 \%)$ women. The average lordosis angle in the study group was $47.07^{\circ}$, standard deviation 9.04, median value was 47.50; the range between lower and upper quartile was $44-54$, and the total range was 24-64. A statistically significant difference was noted in terms of lumbar lordosis between the two groups, $p=0.047$ (Table 2).

The incidence of scoliotic posture and scoliosis was determined by taking into account the values of three variables: pelvic tilt in millimetres, lateral deviation in millimetres and surface rotation expressed in degrees. In women after mastectomy, 4 (13.3\%) women exhibited scoliosis, while 4 (13.3\%) patients also demonstrated scoliotic posture. The control group included $3(10 \%)$ scoliosis cased and 7 (23.3\%) with scoliotic posture. Considering scoliosis angle, in 21 (70\%) subjects, the right side dominated (in the thoracic spine in 11 women, in the thoraco lumbar segment, 6 women, in the lumbar spine, 4 women). Then, analysis of body

Table 1. Descriptive statistics of the analysed scales (1 - study group, 2 - control group)

\begin{tabular}{|c|c|c|c|c|c|c|c|c|c|}
\hline \multirow{2}{*}{$\begin{array}{l}\text { Analysed } \\
\text { scales }\end{array}$} & \multicolumn{8}{|c|}{ Descriptive statistics of the analysed scales } & \multirow{2}{*}{$\begin{array}{c}\text { Mann-Whitney } \\
U \text { test, } p\end{array}$} \\
\hline & Group & Mean & $\begin{array}{l}\text { Standard } \\
\text { deviation }\end{array}$ & $\begin{array}{l}\text { Mini- } \\
\text { mum }\end{array}$ & $\begin{array}{l}\text { Lower } \\
\text { quartile }\end{array}$ & Median & $\begin{array}{l}\text { Upper } \\
\text { quartile }\end{array}$ & $\begin{array}{l}\text { Maxi- } \\
\text { mum }\end{array}$ & \\
\hline \multirow[t]{2}{*}{ Age [years] } & 1 & 55.07 & 4.71 & 45.00 & 52.00 & 55.50 & 60.00 & 60.00 & \multirow[t]{2}{*}{$<0.001$} \\
\hline & 2 & 50.27 & 5.13 & 45.00 & 46.00 & 49.00 & 53.00 & 69.00 & \\
\hline \multirow[t]{2}{*}{ Height $[\mathrm{cm}]$} & 1 & 163.03 & 4.49 & 152.00 & 161.00 & 164.00 & 165.00 & 173.00 & \multirow[t]{2}{*}{0.622} \\
\hline & 2 & 162.40 & 4.76 & 152.00 & 160.00 & 164.00 & 165.00 & 176.00 & \\
\hline \multirow[t]{2}{*}{ Weight $[\mathrm{kg}]$} & 1 & 73.01 & 12.93 & 46.50 & 63.30 & 69.75 & 82.40 & 104.50 & \multirow[t]{2}{*}{0.021} \\
\hline & 2 & 65.95 & 11.21 & 49.90 & 56.90 & 62.30 & 74.60 & 92.90 & \\
\hline \multirow[t]{2}{*}{ BMI $\left[\mathrm{kg} / \mathrm{m}^{2}\right]$} & 1 & 27.56 & 5.32 & 18.20 & 22.90 & 26.65 & 31.00 & 40.10 & \multirow[t]{2}{*}{0.049} \\
\hline & 2 & 24.96 & 3.73 & 18.60 & 22.00 & 24.40 & 27.50 & 32.80 & \\
\hline
\end{tabular}


Table 2. Descriptive statistics regarding the analysed parameters of body posture in women after mastectomy and in the control group (1 - study group, 2 - control group)

\begin{tabular}{|c|c|c|c|c|c|c|c|c|c|}
\hline \multirow{2}{*}{$\begin{array}{l}\text { Body posture } \\
\text { variables }\end{array}$} & \multicolumn{8}{|c|}{ Descriptive statistics of the analysed scales } & \multirow{2}{*}{$\begin{array}{c}\text { Mann-Whitney } \\
U \text { test, } p\end{array}$} \\
\hline & Group & Mean & $\begin{array}{l}\text { Standard } \\
\text { deviation }\end{array}$ & $\begin{array}{l}\text { Mini- } \\
\text { mum }\end{array}$ & $\begin{array}{l}\text { Lower } \\
\text { quartile }\end{array}$ & Median & $\begin{array}{l}\text { Upper } \\
\text { quartile }\end{array}$ & $\begin{array}{l}\text { Maxi- } \\
\text { mum }\end{array}$ & \\
\hline \multirow{2}{*}{$\begin{array}{l}\text { Kyphotic angle } \\
\text { ICT-ITL max. }\end{array}$} & 1 & 57.13 & 11.70 & 33.00 & 47.00 & 58.50 & 62.00 & 80.00 & \multirow[t]{2}{*}{0.200} \\
\hline & 2 & 52.77 & 9.32 & 31.00 & 49.00 & 54.00 & 60.00 & 66.00 & \\
\hline \multirow{2}{*}{$\begin{array}{l}\text { Lordotic angle } \\
\text { ITL-ILS max. }\end{array}$} & 1 & 53.43 & 12.81 & 27.00 & 44.00 & 54.50 & 59.00 & 79.00 & \multirow[t]{2}{*}{0.047} \\
\hline & 2 & 47.07 & 9.04 & 24.00 & 44.00 & 47.50 & 54.00 & 64.00 & \\
\hline \multirow[t]{2}{*}{ Scoliotic angle $\left[{ }^{\circ}\right]$} & 1 & 17.93 & 8.67 & 9.00 & 13.00 & 16.00 & 19.00 & 48.00 & \multirow[t]{2}{*}{0.139} \\
\hline & 2 & 14.53 & 5.72 & 5.00 & 10.00 & 14.00 & 19.00 & 27.00 & \\
\hline \multirow{2}{*}{$\begin{array}{l}\text { Trunk imbalance } \\
\text { VP-DM [mm] }\end{array}$} & 1 & 10.80 & 8.71 & 0.00 & 3.00 & 10.50 & 18.00 & 36.00 & \multirow[t]{2}{*}{0.923} \\
\hline & 2 & 10.90 & 9.19 & 2.00 & 5.00 & 8.00 & 14.00 & 41.00 & \\
\hline \multirow{2}{*}{$\begin{array}{l}\text { Lateral deviation } \\
\text { VP-DM (rms) [mm] }\end{array}$} & 1 & 6.70 & 3.83 & 2.00 & 4.00 & 6.00 & 9.00 & 14.00 & \multirow[t]{2}{*}{0.206} \\
\hline & 2 & 5.67 & 3.54 & 1.00 & 3.00 & 4.00 & 9.00 & 12.00 & \\
\hline \multirow[t]{2}{*}{ Pelvic tilt [mm] } & 1 & 5.90 & 5.92 & 0.00 & 3.00 & 4.50 & 6.00 & 24.00 & \multirow[t]{2}{*}{0.975} \\
\hline & 2 & 7.60 & 11.89 & 0.00 & 3.00 & 3.00 & 6.00 & 54.00 & \\
\hline \multirow[t]{2}{*}{ Pelvic torsion $\left[{ }^{\circ}\right]$} & 1 & 3.03 & 1.96 & 0.00 & 2.00 & 3.00 & 4.00 & 9.00 & \multirow[t]{2}{*}{0.415} \\
\hline & 2 & 3.63 & 6.41 & 0.00 & 1.00 & 2.00 & 4.00 & 36.00 & \\
\hline \multirow{2}{*}{$\begin{array}{l}\text { Surface rotation } \\
\text { [rms] }\end{array}$} & 1 & 4.80 & 3.14 & 1.00 & 3.00 & 4.00 & 5.00 & 18.00 & \multirow[t]{2}{*}{0.216} \\
\hline & 2 & 3.77 & 1.81 & 1.00 & 2.00 & 4.00 & 5.00 & 8.00 & \\
\hline \multirow{2}{*}{$\begin{array}{l}\text { Trunk length } \\
\text { VP-DM [mm] }\end{array}$} & 1 & 426.90 & 41.02 & 348.00 & 392.00 & 433.50 & 457.00 & 509.00 & \multirow[t]{2}{*}{0.935} \\
\hline & 2 & 426.10 & 27.97 & 355.00 & 410.00 & 423.00 & 449.00 & 477.00 & \\
\hline \multirow{2}{*}{$\begin{array}{l}\text { Trunk length } \\
\text { VP-SP [mm] }\end{array}$} & 1 & 480.37 & 40.58 & 400.00 & 455.00 & 475.00 & 501.00 & 577.00 & \multirow[t]{2}{*}{0.935} \\
\hline & 2 & 478.80 & 30.14 & 406.00 & 460.00 & 474.00 & 499.00 & 548.00 & \\
\hline
\end{tabular}

posture parameters depending on mastectomy side was performed. The Mann-Whitney $U$ test showed a statistically significant difference in the pelvic tilt parameter between the group of women after rightand left-sided mastectomy $(p=0.034)$. Higher parameters were observed in women following mastectomy on the right side. Patients after left side surgery demonstrated a higher scoliosis angle, vertical deviation, lateral deviation and surface rotation relative to the compared test group. In addition, women after leftsided mastectomy had lower values of parameters such as kyphosis and lordosis angle, pelvic tilt and torsion, compared to women after right-sided mastectomy. No statistical significance was found between scoliosis angle and the side of the performed surgery, $p=0.075$. The above results of analysis were close to statistical significance, $p=0.05$ (Table 3).

There are many existing works related to the influence of mastectomy on the motor apparatus, quality of life and mental state of the subjects. However, no reliable reports are available regarding the effect of breast amputation on body posture [3]. Future consequences of oncological treatment of breast cancer may be muscular imbalance in the chest wall area, and then the postural muscles, which may lead to postural defects $[2,10,11]$. The proposed approach to the topic is an attempt to look at body posture differently. In the case of women after mastectomy, this is an innovative approach, which is why it is difficult to respond to the reports of researchers who have analysed similar topics in an analogous dimension. This should be based mainly on reports regarding general regularities and phenomena occurring during the assessment of posture defects $[10,12]$. Breast amputation has negative effects on body posture, the musculoskeletal system, coordination and general physical fitness of women after radical mastectomy $[13,14]$. Asymmetrical positioning of the shoulder line (shoulder blade elevation on the affected site) is a common result of unilateral mastectomy [15-17]. Maintaining dynamic balance in this case may constitute differences in the context of deviations of the body in the frontal plane due to the side of the performed surgery [18-20]. In addition, the state of uneven weight distribution adversely affects 
Table 3. Descriptive statistics regarding the analysed parameters of body posture depending on side of performed mastectomy ( $\mathrm{R}$ - right-sided mastectomy, $\mathrm{L}$ - left-sided mastectomy)

\begin{tabular}{|c|c|c|c|c|c|c|c|c|c|}
\hline \multirow{2}{*}{$\begin{array}{l}\text { Body posture } \\
\text { variables }\end{array}$} & \multicolumn{8}{|c|}{ Descriptive statistics of the analysed scales } & \multirow{2}{*}{$\begin{array}{l}\text { Mann- } \\
\text { Whitney } \\
U \text { test, } p\end{array}$} \\
\hline & $\begin{array}{c}\text { Side of } \\
\text { mastectomy }\end{array}$ & Mean & $\begin{array}{l}\text { Standard } \\
\text { deviation }\end{array}$ & $\begin{array}{l}\text { Mini- } \\
\text { mum }\end{array}$ & $\begin{array}{l}\text { Lower } \\
\text { quartile }\end{array}$ & Median & $\begin{array}{l}\text { Upper } \\
\text { quartile }\end{array}$ & $\begin{array}{l}\text { Maxi- } \\
\text { mum }\end{array}$ & \\
\hline \multirow{2}{*}{$\begin{array}{l}\text { Kyphotic angle } \\
\text { ICT-ITL max. }\end{array}$} & $\mathrm{R}$ & 58.06 & 12.89 & 33.00 & 47.00 & 60.00 & 62.00 & 80.00 & \multirow[t]{2}{*}{0.502} \\
\hline & L & 55.92 & 10.32 & 40.00 & 51.00 & 55.00 & 61.00 & 74.00 & \\
\hline \multirow{2}{*}{$\begin{array}{l}\text { Lordotic angle } \\
\text { ITL-ILS max. }\end{array}$} & $\mathrm{R}$ & 53.88 & 9.06 & 36.00 & 49.00 & 54.00 & 58.00 & 67.00 & \multirow[t]{2}{*}{0.850} \\
\hline & L & 52.85 & 16.92 & 27.00 & 41.00 & 55.00 & 59.00 & 79.00 & \\
\hline \multirow{2}{*}{$\begin{array}{l}\text { Scoliotic } \\
\text { angle }\left[^{\circ}\right]\end{array}$} & $\mathrm{R}$ & 15.18 & 4.61 & 9.00 & 12.00 & 15.00 & 18.00 & 25.00 & \multirow[t]{2}{*}{0.075} \\
\hline & L & 21.54 & 11.33 & 11.00 & 16.00 & 17.00 & 22.00 & 48.00 & \\
\hline \multirow{2}{*}{$\begin{array}{l}\text { Trunk imbalance } \\
\text { VP-DM [mm] }\end{array}$} & $R$ & 9.41 & 9.21 & 0.00 & 3.00 & 6.00 & 12.00 & 36.00 & \multirow[t]{2}{*}{0.185} \\
\hline & L & 12.62 & 8.01 & 2.00 & 3.00 & 12.00 & 18.00 & 24.00 & \\
\hline \multirow{2}{*}{$\begin{array}{l}\text { Lateral deviation } \\
\text { VP-DM (rms) [mm] }\end{array}$} & $R$ & 6.06 & 3.45 & 2.00 & 3.00 & 5.00 & 8.00 & 14.00 & \multirow[t]{2}{*}{0.158} \\
\hline & L & 8.00 & 3.92 & 3.00 & 5.00 & 6.00 & 13.00 & 14.00 & \\
\hline \multirow{2}{*}{$\begin{array}{l}\text { Pelvic tilt } \\
{[\mathrm{mm}]}\end{array}$} & $R$ & 7.76 & 6.71 & 3.00 & 3.00 & 6.00 & 9.00 & 24.00 & \multirow[t]{2}{*}{0.034} \\
\hline & L & 3.46 & 3.64 & 0.00 & 0.00 & 3.00 & 6.00 & 12.00 & \\
\hline \multirow{2}{*}{$\begin{array}{l}\text { Pelvic } \\
\text { torsion }\left[^{\circ}\right]\end{array}$} & $R$ & 2.94 & 2.08 & 0.00 & 1.00 & 3.00 & 4.00 & 9.00 & \multirow[t]{2}{*}{0.625} \\
\hline & L & 3.15 & 1.86 & 0.00 & 2.00 & 3.00 & 4.00 & 6.00 & \\
\hline \multirow{2}{*}{$\begin{array}{l}\text { Surface rotation } \\
\text { [rms] }\end{array}$} & $R$ & 4.29 & 2.14 & 2.00 & 3.00 & 4.00 & 5.00 & 11.00 & \multirow[t]{2}{*}{0.941} \\
\hline & L & 5.46 & 4.12 & 1.00 & 4.00 & 5.00 & 5.00 & 18.00 & \\
\hline \multirow{2}{*}{$\begin{array}{l}\text { Trunk length } \\
\text { VP-DM [mm] }\end{array}$} & $R$ & 433.41 & 36.53 & 362.00 & 404.00 & 438.00 & 463.00 & 490.00 & \multirow[t]{2}{*}{0.286} \\
\hline & L & 418.38 & 46.36 & 348.00 & 388.00 & 417.00 & 455.00 & 509.00 & \\
\hline \multirow{2}{*}{$\begin{array}{l}\text { Trunk length } \\
\text { VP-SP [mm] }\end{array}$} & $R$ & 490.41 & 36.70 & 441.00 & 577.00 & 489.00 & 501.00 & 577.00 & \multirow[t]{2}{*}{0.126} \\
\hline & L & 467.23 & 43.06 & 400.00 & 437.00 & 467.00 & 496.00 & 558.00 & \\
\hline
\end{tabular}

body posture. Body posture plays a very important role in assessing the general physical predisposition of humans. It indicates whether the body is developing properly and whether the fitness range deviates from the accepted norm. It can be distorted due to injuries, trauma, illnesses, bad habits, lifestyle or external factors. Over time, the body compensates for incorrect posture, treating it as the only acceptable form [8].

In the authors' study, a tendency was observed in patients after radical surgery indicating worsening of thoracic kyphosis (56.7\%) and lumbar lordosis (70\%) relative to the control group (respectively: kyphosis angle 57.13 and 52.77, lordosis angle 53.43 and 47.07). Statistically significant differences were noted in lordosis angle of the lumbar segment between the two groups, $p=0.047$.

In the research by Rahimi and Haghighat [21], it was also found that increased thoracic kyphosis in women after mastectomy occurred in comparison to the control group. The average degree of kyphosis was 55.28 and 40.59 in both groups, while lordosis was 50.74 and 48.38, respectively. In addition, Mangone et al. [22] evaluated body posture of women after breast cancer treatment using the Formetric 4D raster stereography process. In the study group, greater limitations were found in the sagittal plane of the spine in the case of flexion of the anterior-posterior trunk and the inversion point of the lumbosacral segment more than a larger pelvic tilt. Hojan et al. [23] examined 51 women after unilateral mastectomy and divided the group according to operated side. They assessed body posture using the electromyographic activity of the erector spinae extensor muscle with 4 different weight-varying breast prostheses. The weight of the external breast prosthesis did not affect the differences in erector spinae muscle activity on the operated or non-operated sides.

In this study, the scoliosis angle in the study group was higher compared to the control group. The incidence of scoliotic posture and scoliosis was determined by considering three values: pelvic tilt in millimetres, lateral deviation in millimetres and surface rotation expressed in degrees. Scoliotic posture occurred when pelvic tilt and lateral deflection were be- 
low $5 \mathrm{~mm}$ and the surface rotation was lower than $5^{\circ}$. In contrast, scoliosis was present when pelvic tilt and lateral deflection were greater than $5 \mathrm{~mm}$ and surface rotation was higher than $5^{\circ}$. To assess the occurrence of scoliotic posture or scoliosis, all 3 conditions must be met. In the absence of these 3 requirements, it is assumed that scoliosis or scoliotic posture does not occur. In the case of women after mastectomy, 4 (13.3\%) women exhibited scoliosis, while 7 (23.3\%) patients demonstrated scoliotic posture. Taking scoliosis angle onto account, 21 (70\%) subjects had right-sided dominance (in the thoracic spine - 11 women, in the thoracolumbar segment -6 women, in the lumbar spine area -4 women).

Psychological problems are often found in women treated for breast cancer, which are usually greater the larger the functional deficits. Breast loss due to mastectomy can cause many physiological and psychosocial problems associated with changes in body image, self-esteem or emotions $[24,25]$. The habitual adoption of kyphotic body posture may be associated with the psychogenic aspect - masking breast loss or weakening of the strength of muscles damaged during surgery, and the protractive reflex position of the shoulder on the operated side [26]. Related overloads are transmitted to the bone parts of the vertebrae and intervertebral discs, becoming one of the causes of pain syndromes, which may affect the formation of postural defects in the future [27]. Somatic (morphological), neurophysiological and psychosocial factors should all be considered in the prevention and correction of posture defects [28]. In addition to postural defects, the consequence of mastectomy may be a disturbance in statics and body balance. Disturbances in postural coordination may be associated with unevenly distributed postural muscle tension or abnormal body mass [29]. Bieniek and Wilczyński [30] showed a connection between parameters of body posture and postural stability, which is important in re-education of body posture. This connection indicates the inclusion of central stabilization exercises, which are the basis for equalizing muscular imbalance and controlling the correct positioning of the spine [30]. The main objective of postural re-education is to eliminate existing defects or to hinder their progression. It is important to improve the habit of correct body posture, by stretching and strengthening the appropriate muscle groups depending on the strength balance and muscle length assumed in advance [31-33].

\section{Conclusions}

Mastectomy surgery changes body posture in the sagittal plane. Among women treated for breast cancer, there is an increase in thoracic kyphosis and lumbar lordosis. In the case of women following left-sided mastectomy, a higher scoliosis angle was demonstrated, as well as deviation from the vertical line, lateral deviation and surface rotation compared to women after right-sided mastectomy.

\section{Conflict of interest}

The authors declare no conflict of interest.

\section{References}

1. Malicka I, Barczyk K, Hanuszkiewicz J, Skolimowska B, Woźniewski M. Body posture of women after breast cancer treatment. Ortop Traumatol Rehabil 2010; 12: 353361.

2. Akoochakian M, Davari HA, Alizadeh MH, Rahnama N. Evaluation of shoulder girdle strength more than 12 month after modified radical mastectomy and axillary nodes dissection. J Res Med Sci 2017; 22: 81.

3. Rachwał M, Drzał-Grabiec J, Walicka-Cupryś K, Truszczyńska A. Control of static balance among women after mastectomy. Vision impast on the quality of the equilibrium response. Post Rehabil 2013; 3: 13-20.

4. Wilczyński J. Posturologia - nauka o postawie ciała człowieka. Studia Medyczne 2011; 23: 7-17.

5. Błaszczyk J, Beck M, Sadowska D. Assessment of postural stability in young healthy subjects based on directional features of posturographic data: vision and gender effects. Acta Neurobiol Exp 2014; 74: 433-442.

6. Jeong JH, Choi B, Chang SY, Kim EK, Kang E, Heo CY, Myung Y. The effect of immediate breast reconstruction on thoracic spine alignment after unilateral mastectomy. Clin Breast Cancer 2018; 18: 214-219.

7. Mesyasz E, Milan M, Juzwiszyn J, Maj A, Matuszewska M, Chabowski M, Janczak D. Lymphedema in women undergoing mastectomy due to breast cancer. Med Rodz 2018; 21: 116-120.

8. Paprocki M, Rychter P, Wilczyński J. Accuracy of the optoelectronic test body posture Formetric Diers Method III $4 \mathrm{D}$ in comparison with the result of the $\mathrm{x}$-ray pictures. J Educ Health Sport 2016; 6: 385-398.

9. Harzmann HC. Optischer Gipsabdruckhilftbei der Rückenanalyse. Süddeutscher Orthopädenkongress. Kongressausgabe 1999; 2: 15.

10. Hojan K, Wruk B, Stryła W. The impact of treatment in breast cancer on back pain. Onkol Pol 2010; 4: 177-184.

11. Lee CE, Warden SJ, Szuck B, Lau YKJ. Preliminary study on the efficacy of a community-based physical activity intervention on physical function-related risk factors for falls among breast cancer survivors. Am J Phys Med Rehabil 2016; 95: 561-750.

12. Głowacka I, Nowikiewicz T, Hagner W, Nowacka K, Sowa M, Zegarski W. Sagittal plane postural changes in female patients with breast cancer after different surgical techniques. Breast J 2017; 23: 109-111.

13. Czerniak U, Demuth A, Krzykala M, Ziółkowska-Łajp E. Body fat and quality of life in women treated for breast cancer. Stud Phys Culture Tourism 2012; 19: 21-24.

14. Nissen MJ, Shapiro A, Swenson KK. Changes in weight and body composition in women receiving chemotherapy for breast cancer. Clin Breast Cancer 2011; 11: 52-60.

15. Drżał-Grabiec J, Rachwał M, Walicka-Cupryś K. Postawa ciała kobiet po mastektomii. Onkol Pol 2013; 16: 11-15.

16. Karczewska E, Szlachta P, Pytka K, Hałasa-Majchrzak D, Majcher P. Kinesio Taping Method in the asymmetry tre- 
atment of the shoulder girdle in women after mastectomy - a pilot study. Eur J Med Technol 2016; 1: 37-43.

17. Serel S, Tuzlalı ZY, Akkaya Z, Uzun C, Kaya B, Bayar S. Physical effects of unilateral mastectomy on spine deformity. Clin Breast Cancer 2017; 17: 29-33.

18. Atanes Mendes Peres AC, Dias de Oliveira Latorre MD, Yugo Maesaka J, Filassi JR, Chada Baracat E, Alves Goncalves Ferreira E. Body posture after mastectomy: comparison between immediate breast reconstruction versus mastectomy alone. Physiother Res Int 2017; 22: e1642.

19. Głowacka I, Nowikiewicz T, Siedlecki Z, Hagner W, Nowacka $\mathrm{K}$, Zegarski $\mathrm{W}$. The assessment of the magnitude of frontal plane postural changes in breast cancer patients after breast-conserving therapy or mastectomy - follow-up results 1 year after the surgical procedure. Pathol Oncol Res 2016; 22: 203-208.

20. Kabała M, Wilczyński J. Evaluation of equivalent reactions in women after mastectomy using biodex balance system. J Educ Health Sport 2017; 7: 565-578.

21. Rahimi F, Haghighat S. Comparison of thoracic kyphosis and lumbar lordosisin breast cancer survivors compared to healthy women. Iran Quart J Breast Dis 2016; 9: 36-42.

22. Mangone M, Bernetti A, Agostini F, Paoloni M, De Cicco FA, Capobianco SV, Bai AV, Bonifacino A, Santilli V, Paolucci T. Changes in spine alignment and postural balance after breast cancer surgery: a rehabilitative point of view. Biores Open Access 2019; 8: 121-128.

23. Hojan K, Manikowska F, Chen BPJ, Lin CC. The influence of an external breast prosthesis on the postureofwomenafter mastectomy. J Back Musculoskel Rehabil 2016; 29: 337-342.

24. Brunault P, Champagne AL, Hugue G, Suanne I, Senon JL, Body G, Rusch E, Magnin G, Voyer M, Reveillere C, Camus V. Major depressive disorder, personality disorders, and coping strategies are independent risk factors for lower quality of life in non-metastatic breast cancer patients. Psychooncology 2016; 25: 513-520.

25. Grogan S, Mechan J. Body image after mastectomy: a thematic analysis of younger women's written accounts. J Health Psychol 2017; 22: 1480-1490.

26. Koçan S, Gürsoy A. Body image of women with breast cancer after mastectomy: a qualitative research. J Breast Health 2016; 12: 145-150.

27. Mafu TS, September AV, Shamley D. The potential role of angiogenesis in the development of shoulder pain, shoulder dysfunction, and lymphedema after breast cancer treatment. Cancer Manag Res 2018; 10: 81-90.

28. Wilczyński J, Bieniek K. Correlations of somatic traits and postural defects in girls and boys aged 10-12. Acta Bioeng Biomech 2019; 21: 79-86.

29. Kabała MM, Wilczyński J. Obesity and postural stability in women after mastectomy. Medical Studies 2019; 35: 48-54.

30. Bieniek K, Wilczyński J. Analysis of the relationship between body posture and postural stability in girls aged 10-12 years. Medical Studies 2019; 35: 55-60.

31. Kim HY, Cha YH, Chun YS, Shin HS. Correlation of the torsion values measured by rotational profile, kinematics, and CT study in CP patients. Gait Posture 2017; 57: 241-245.

32. Margalit A, McKean G, Constantine A, Thompson CB, Lee RJ, Sponseller PD. Body mass hides the curve: thoracic scoliometer readings vary by body mass index value. J Pediatr Orthop 2017; 37: e255-e260.
33. Monticone M, Ambrosini E, Cazzaniga D, Rocca B, Motta L, Cerri C, Brayda-Bruno M, Lovi A. Adults with idiopathic scoliosis improve disability after motor and cognitive rehabilitation: results of a randomised controlled trial. Eur Spine J 2016; 25: 3120-3129.

\section{Address for correspondence:}

\section{Magdalena M. Kabała MSc}

Medical College

Jan Kochanowski University

Świętokrzyskie Centre of Onclogy

Kielce, Poland

Phone: +48 507579225

E-mail: magdalena.kabala@onet.eu 